(c) 2018 - ISSN 1807-2577

\title{
Accuracy evaluation of tridimensional images performed by portable stereophotogrammetric system
}

\author{
Avaliação da acurácia de imagens tridimensionais realizadas em sistema de \\ estereofotogrametria portátil
}

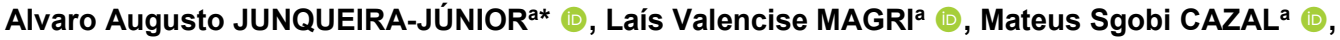
Aline Akemi MORI ${ }^{a} \mathbb{D}^{\mathbb{D}}$, Ana Maria Bettoni RODRIGUES DA SILVA ${ }^{\mathrm{a}} \mathbb{C}^{\mathbb{D}}$, Marco Antônio Moreira RODRIGUES DA SILVA ${ }^{\mathrm{a}}$ (1)
\end{abstract}

aUSP - Universidade de São Paulo, Faculdade de Odontologia de Ribeirão Preto, Departamento de Odontologia Restauradora, Ribeirão Preto, SP, Brasil

How to cite: Junqueira-Júnior AA, Magri LV, Cazal MS, Mori AA, Rodrigues da Silva AMB, Rodrigues da Silva MAM. Accuracy evaluation of tridimensional images performed by portable stereophotogrammetric system. Rev Odontol UNESP. 2019;48:e20190089. https://doi.org/10.1590/1807-2577.08919

\begin{abstract}
Resumo
Introdução: A configuração e o formato das estruturas craniofaciais, a oclusão dentária, a musculatura orofacial bem como a harmonia facial são determinantes para as características próprias da face humana. Instrumentos manuais como paquímetro e fitas métricas têm sido tradicionalmente utilizados para realizar as medidas antropométricas, diretamente de um sujeito em ambiente clínico. 0 avanço tecnológico possibilitou transformar a aquisição destas medidas analógicas em medições digitais, tornando possível aquisições rápidas, precisas e sem radiação. Tais informações podem, ainda, ser arquivadas para futuras análises e compartilhamento de informações com colegas e pacientes. A estereofotogrametria tem se destacado dentre as novas técnicas de captação de imagens tridimensionais, onde um grupo de câmeras de rápida captura fotografam a imagem do indivíduo a partir de variadas angulações. Atualmente, sistemas portáteis de estereofotogrametria vêm sendo propostos no mercado por apresentarem maior praticidade e simplicidade no manuseio. Objetivo: A proposta do presente estudo foi avaliar a precisão e a reprodutibilidade de um sistema de estereofotogrametria 3D portátil (Vectra H1, Canfield Scientific, Fairfield, NJ, EUA) em medições dos tecidos moles faciais de 30 participantes e de um cubo de medidas definidas, comparando tais medidas com as obtidas por um sistema de estereofotogrametria 3D fixo (Vectra M3, Canfield Scientific, Fairfield, NJ, EUA), de precisão e reprodutibilidade estabelecidas e validadas, através de análise quantitativa dos possíveis erros. Material e método: Foram realizadas marcações craniométricas transitórias em tecido mole da face nos 30 participantes do estudo $(n=30)$, sendo estes submetidos à aquisição de imagens pela técnica da estereofotogrametria, tanto pelo sistema fixo Vectra M3, quanto pelo sistema portátil Vectra H1. Trinta pontos de referência (landmarks) foram utilizados para realizar as medidas (em mm) de 34 distâncias. Quanto ao cubo, foram avaliados, no total, 20 ângulos, 20 áreas e 9 distâncias lineares. Resultado: Os resultados obtidos pela metodologia estabelecida mostraram que o sistema portátil Vectra H1 apresentou precisão e repetibilidade comparáveis com o sistema fixo Vectra M3. Conclusão: A análise dos dados, juntamente com a correlação aos achados da literatura, evidenciam a capacidade do Vectra H1 de capturar imagens tridimensionais de modo eficaz, o que torna viável seu uso nas mais diversas aplicações clínicas.
\end{abstract}

Descritores: Estereofotogrametria; antropometria; face.

\begin{abstract}
Introduction: Human facial characteristics vary according to individual dental occlusion, facial harmony, orofacial musculature and the format and configuration of craniofacial structures. Traditionally, anthropometric measurements have been acquired through direct evaluation of subjects in a clinical
\end{abstract}


environment using calipers and metric tapes to measure distances between arches and landmarks. Scientific breakthroughs have enabled the digitization of data and introduced the possibility of quick, precise, radiation-free acquisitions; details can be archived for future analysis and easily shared with patients and colleagues. Among new facial analysis methods, the stereophotogrammetry technique has emerged, which uses a group of cameras to take many photographs of a subject in rapid succession from multiple angles. Nowadays, portable stereophotogrammetric systems are being proposed, as they are more practical and easier to use. Objective: The aim of this work was to analyze the accuracy and reproducibility of a portable 3D stereophotogrammetric system (Vectra H1, Canfield, Fairfield, NJ, USA) in measuring soft facial tissues of 30 participants, defining measures of a cube and comparing these measurements with those obtained by a set 3D stereophotogrammetric system (Vectra M3, Canfield, Fairfield, NJ, USA) with previously validated accuracy and reproducibility through quantitative analysis of possible errors. Material and method: Thirty temporary landmarks were used to measure (in $\mathrm{mm}$ ) 34 distances in 30 participants $(n=30)$. Regarding the cube, 12 angles and 9 linear distances were evaluated. Result: The results obtained by the established methodology indicated that the Vectra H1 portable system has shown accuracy and reproducibility equal to that of the Vectra M3 set system. Conclusion: Data analysis and correlation to literature findings show Vectra H1's capability to reliably capture tridimensional images, which makes it practical for use in diverse clinical applications.

Descriptors: Stereophotogrammetry; anthropometry; face.

\section{INTRODUCTION}

Anthropometry is the science of measuring the human body through assessments of weight, size and proportion to provide valuable objective lessons on how to evaluate and characterize phenotypic variations and dysmorphologies in any species ${ }^{1}$. Facial anthropometry through the scope of dentistry provides more than merely descriptive results ${ }^{2}$. The possibilities of communication, interaction with the environment, facial identification and ability to disseminate individual health information have long attracted the attention of scientists and artists, who seek to analyze it quantitatively-9. A precise face analysis is indispensable for diagnosis and preparation of treatment plans for patients experiencing orthodontic treatment, orthognathic and plastic surgery or genetic or acquired malformations; for the study of normal and abnormal growth of the face and for anthropometric investigations, 5 -13.

Modern technologies have been employed in phenotypic studies ${ }^{14-18}$, enabling the creation of valuable databases of normative values for each population. Such advancement undoubtedly facilitates an understanding of the craniofacial complex in various ethnic groups ${ }^{19,20}$.

Among three-dimensional methods of analysis, stereophotogrammetry has been proven to be precise and repeatable2,12,21-23. This method does not require physical contact between the patient's face and the apparatus; it is safe, fast, non-invasive ${ }^{2}$ and makes it possible to obtain a high-quality image of the external surface. In Brazil, Junqueira et al. ${ }^{24}$ and Andrade et al. ${ }^{25}$ have worked with stereophotogrammetry; Junqueira et al. ${ }^{24}$ executed an anthropometric analysis of a group of healthy young Brazilians using the Vectra M3 fixed stereophotogrammetry system. Andrade et al. ${ }^{25}$ investigated the repeatability of the same digital system in linear and angular measurements for facial morphology analysis, observing good repeatability and accurate measurements within the parameters of her study.

Portable stereophotogrammetry systems are increasingly being proposed because they present greater practicality and simplicity of handling than stationary systems. There is a paucity of studies evaluating the efficacy of the portable stereophotogrammetry system, which is important for its independent technical validation.

Camison et al.26 carried out a study to validate the Vectra $\mathrm{H} 1$ portable stereophotogrammetry system by evaluating 136 linear distances in 26 participants. More research and robust comparison of data is necessary to safely validate the use of three- 
dimensional images via portable stereophotogrammetry apparatus in the analysis of linear distances, areas and angles.

The aim of the present study was to evaluate the accuracy and reproducibility of a portable 3D stereophotogrammetry system (Vectra H1, Canfield Scientific, Fairfield, NJ, USA) for the measurement of linear distances of soft facial tissues in 30 participants and linear distances/angles in a cube of known dimensions, comparing results to those of an established and validated fixed 3D stereophotogrammetry system (Vectra M3, Canfield Scientific, Fairfield, NJ, USA) through quantitative analysis of possible errors.

\section{MATERIAL AND METHOD}

\section{Sample Selection}

The sample size was determined considering the mean difference between $1 \mathrm{~mm}$ acquisitions (standard deviation $=1$ ) with an $\alpha$ error set at $0.05^{10,12}$ and a $\beta$ error adjusted to $0.8^{2}$. As inclusion criteria, chosen participants were aged between 18 and 40 years and without facial scars, congenital anomalies and/or motor deficiencies that could interfere with patients' stability during image acquisition and thus generate inaccuracies in the capture of images that were not inherent to the stereophotogrammetry imaging devices. Participants were chosen randomly regardless of skin color, weight or height. The data obtained by the two Vectra stereophotogrammetry systems (M3 and H1) were compared, using the same participants and the same object for both systems.

\section{Test of Precision in Object's Image}

One of the steps in evaluating the Vectra H1 system's accuracy was to take images of a standard object with a millimeter grid over its body; researchers acquired images with the Vectra H1 system and the Vectra M3 system, which has been proven to be efficient and precise ${ }^{2}$.

\section{Facial Measurements}

All the procedures were non-invasive and performed with minimal discomfort for the participants as previously clarified. All participants signed an informed consent and the project was duly registered in the Brazil Platform under CAAE 55348215.1.0000.5419.

The most common errors in stereophotogrammetric image capturing occur during the identification of landmarks and the capture of the image itself. In this work, landmarks were adequately identified prior to the capture of images to obtain reliable results, a practice also performed in other studies in the literature $2,10,27,28$.

It is important for an experienced operator to be responsible for establishing landmarks and capturing images, as the correct identification and demarcation of landmarks depends on his/her knowledge, which is also indispensable for recognizing factors that alter the positioning of soft tissues while capturing images ${ }^{19}$.

Before placing the landmarks, each participant was given a hair band to pull the hair away from the face, facilitate access by the operator to mark the landmarks and improve the area's capture by the corresponding stereophotogrammetry system. Sterile gauze soaked in $70 \%$ alcohol was systematically applied to the face of each participant to cleanse the skin of any impurities, oiliness and/or makeup. 
Thirty landmarks were established, as shown in Figure 1, with Make-B liquid eyeliner (O Boticário ${ }^{\circledR}$, Brazil). This procedure was performed by the same operator for all 30 participants, lasting an average of 5 minutes for each participant. The landmarks, Ex[r], Ex[1], $\mathrm{En}[\mathrm{r}], \mathrm{En}[\mathrm{l}], \mathrm{Ch}[\mathrm{r}], \mathrm{Ch}[\mathrm{l}]$ and Sto, were placed directly in the software after image acquisition (without manual eyeliner marking), as they are well delimited by facial anatomy and reproducible in a reliable way ${ }^{29}$.

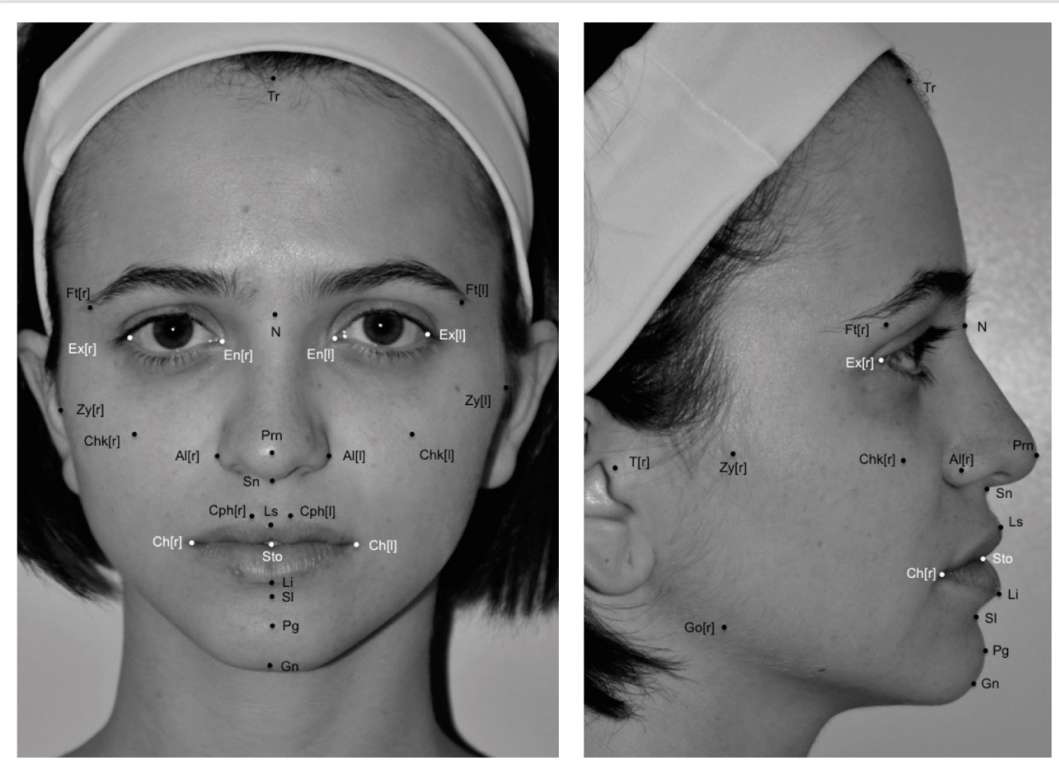

Figure 1. Anterior and lateral view of the face showing the landmarks.

It is important to note that, unlike the acquisition performed by the Vectra M3 fixed stereophotogrammetry system, the Vectra $\mathrm{H} 1$ portable system requires greater attention to the facial expression of the subject at three moments. This is because the Vectra M3 fixed system captures all three angles simultaneously, eliminating the possibility of a change in the positioning of soft tissues between each module's capture. The Vectra H1 portable system requires three acquisitions; changes in facial expression (including changes in the jaw position) may impair accurate three-dimensional reconstruction of the participant's face. The landmarks' digitizing process occurred in a similar way in both systems, as the same software was used.

\section{Statistical Analysis}

Various comparisons were performed to evaluate the Vectra H1 portable system's accuracy. First, we compared all 30 participants' images as captured by both systems. Thirty-four distances were evaluated for each of the 30 participants in both sets, totaling 2040 linear distances. In addition to descriptive analyses, paired Student's t-tests were used to compare the measurements obtained by the Vectra $\mathrm{H} 1$ portable system to the reference values obtained by the Vectra M3 fixed system. As the participants did not have known reference values (this is only possible when dealing with objects of known dimensions), those obtained by the Vectra M3 fixed system were adopted as "real values" because this system has proven efficacy and accuracy ${ }^{2}$. When evaluating a particular method, it must be considered that terms used in extant studies, however similar they may seem, have different meanings.

Two operators analyzed the images acquired by Vectra H1, calculating 34 measurements for each participant. The three-dimensional images of each participant and the demarcated landmarks on the skin were the same for both operators. This step was intended to check for 
possible errors during the process of marking the landmarks in the software. The same statistical tests used in the first analysis were performed at this time, with the addition of the technical error of measurement (TEM), also known as Dahlberg's error.

Thirty-four Bland-Altman charts were developed to measure linear distances of participants with the Vectra $\mathrm{H} 1$ portable system, and 10 Bland-Altman charts were developed for linear and angular cube values. Because it is impossible to detail all of this information in this article, we have chosen to attach 2 Bland-Altman charts, one referring to the distances T[r]-T[l] of the participants and one referring to the distances of points 4 and 6 of the cube. The values indicate the range of $95 \%$ of the measurements made by the operator.

Finally, a cubic object of known dimensions was photographed 10 times by the Vectra H1 portable system and 10 times by the fixed Vectra M3 system (1-week interval between measurements), and a series of distances, areas and angles were analyzed to determine the possible errors that occurred during the capture of the image between the two systems. A cube measuring $10 \mathrm{~cm}$ on each edge was made in the precision workshop of the University of São Paulo (Ribeirão Preto) (Figure 2), being made of wood with a metal rod to assist manipulation. Graphite paper was glued to the cube so that the real size of distances and areas could be compared with the values obtained with three-dimensional analysis. In addition to the descriptive results (average, SD, MD, $p$ and MAD), TEM was used to evaluate random errors between acquisitions by the same device ${ }^{11}$. Nine points were marked digitally on each of the 3 analyzed faces of the cube. The real distance between these points was known due to the industrial precision of the millimeter paper used. First, 12 angles of $90^{\circ}$ at edges were analyzed in the 2 systems. The average, SD, minimum, maximum, REM, MAD and MD of both systems were analyzed, followed by linear distances between points. Each of the 9 distances ( 3 distances on each face) measured $70 \mathrm{~mm}$, having as a real value reference the size represented by the millimeter grid. Finally, the software allows the overlap of two images taken at different times, making it possible to measure the linear distances between the points of these images. In other words, the reference point named " 1 " in the first image had its distance calculated from the " 1 " point of the second image after effective overlap. The greater the distance between two points of the same name, the less system repeatability.

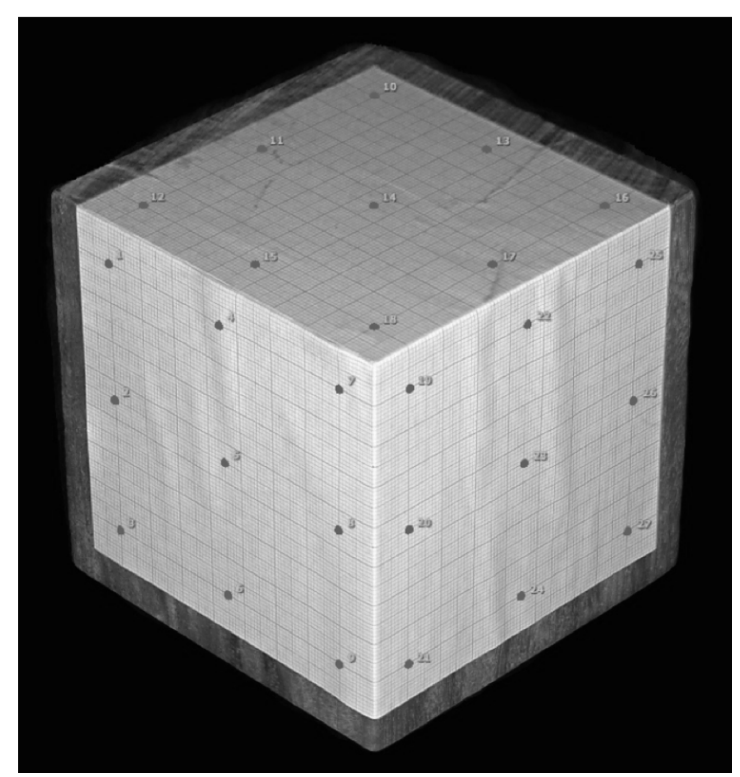

Figure 2. The cube of $10 \mathrm{~cm}$ of edge was made in the Precision Workshop of the University of São Paulo (Ribeirão Preto). 


\section{RESULT}

Thirty participants had their images captured by the Vectra M3 fixed system and the Vectra M1 portable system; 12 men and 18 women.

Table 1 presents the average values and SD of the 34 distances obtained for both stereophotogrammetry systems as well as the MD, the $p$-value (Student's t-test due to parametric values), MAD, ICC and $p$ of ICC. Table 2 lists the values found for each operator with the Vectra H1 portable system, including the average values and SD of the same 34 distances in addition to the MD, the $p$-value (Student's t-test due to parametric values), MAD and TEM.

Table 1. Differences between Vectra M3 and $\mathrm{H} 1$ systems for the same operator

\begin{tabular}{|c|c|c|c|c|c|c|c|c|c|}
\hline \multirow{2}{*}{ Distances } & \multicolumn{2}{|c|}{ Vectra M3 } & \multicolumn{2}{|c|}{ Vectra H1 } & \multirow{2}{*}{ MD } & \multirow{2}{*}{$p$} & \multirow{2}{*}{ MAD } & \multirow{2}{*}{ ICC } & \multirow{2}{*}{$p$ of ICC } \\
\hline & Average & SD & Average & SD & & & & & \\
\hline $\mathrm{T}[\mathrm{r}]-\mathrm{T}[\mathrm{l}]$ & 142.13 & 8.62 & 141.66 & 8.44 & 0.46 & 0.83 & 0.79 & 0.99 & $<0.0001$ \\
\hline $\mathrm{Zy}[\mathrm{r}]-\mathrm{Zy}[\mathrm{l}]$ & 139.11 & 8.39 & 139.20 & 8.31 & -0.09 & 0.95 & 0.31 & 0.99 & $<0.0001$ \\
\hline $\mathrm{Go}[\mathrm{r}]-\mathrm{Go}[\mathrm{l}]$ & 117.04 & 9.69 & 118.36 & 9.72 & -1.31 & 0.57 & 1.38 & 0.98 & $<0.0001$ \\
\hline $\mathrm{Ch}[\mathrm{r}]-\mathrm{Ch}[\mathrm{l}]$ & 50.03 & 4.30 & 49.95 & 4.21 & 0.08 & 0.97 & 0.75 & 0.98 & $<0.0001$ \\
\hline Tr-N & 70.65 & 8.95 & 70.53 & 8.96 & 0.12 & 0.94 & 0.37 & 0.99 & $<0.0001$ \\
\hline N-Sn & 50.54 & 4.45 & 50.48 & 4.39 & 0.06 & 0.84 & 0.20 & 0.99 & $<0.0001$ \\
\hline Sn-Gn & 65.29 & 5.26 & 64.95 & 5.12 & 0.34 & 0.84 & 0.56 & 0.99 & $<0.0001$ \\
\hline $\mathrm{T}[\mathrm{r}]-\mathrm{Go}[\mathrm{r}]$ & 59.40 & 5.96 & 59.57 & 6.09 & -0.17 & 0.90 & 0.70 & 0.98 & $<0.0001$ \\
\hline $\mathrm{T}[\mathrm{l}]-\mathrm{Go}[\mathrm{l}]$ & 60.12 & 6.53 & 60.60 & 6.76 & -0.48 & 0.75 & 0.57 & 0.99 & $<0.0001$ \\
\hline $\mathrm{N}-\mathrm{T}[\mathrm{r}]$ & 117.71 & 6.21 & 117.18 & 6.19 & 0.53 & 0.75 & 0.55 & 0.99 & $<0.0001$ \\
\hline $\mathrm{N}-\mathrm{T}[\mathrm{l}]$ & 116.78 & 6.80 & 116.58 & 6.77 & 0.20 & 0.86 & 0.29 & 0.99 & $<0.0001$ \\
\hline $\mathrm{Sn}-\mathrm{T}[\mathrm{r}]$ & 122.11 & 6.65 & 121.71 & 6.58 & 0.40 & 0.78 & 0.40 & 0.99 & $<0.0001$ \\
\hline Sn-T[l] & 122.12 & 7.05 & 122.16 & 7.04 & -0.04 & 0.98 & 0.29 & 0.99 & $<0.0001$ \\
\hline $\mathrm{Pg}-\mathrm{T}[\mathrm{r}]$ & 137.59 & 8.43 & 137.25 & 8.27 & 0.34 & 0.89 & 0.59 & 0.99 & $<0.0001$ \\
\hline Pg-T[1] & 137.63 & 8.32 & 137.70 & 8.39 & -0.07 & 1.00 & 0.37 & 0.99 & $<0.0001$ \\
\hline $\mathrm{Pg}-\mathrm{Go}[\mathrm{r}]$ & 95.48 & 7.44 & 94.70 & 7.17 & 0.78 & 0.68 & 0.78 & 0.98 & $<0.0001$ \\
\hline Pg-Go[l] & 96.08 & 6.15 & 95.45 & 6.06 & 0.63 & 0.70 & 0.86 & 0.98 & $<0.0001$ \\
\hline $\mathrm{Ft}[\mathrm{r}]-\mathrm{Ft}[\mathrm{l}]$ & 110.59 & 5.54 & 110.48 & 5.56 & 0.11 & 0.90 & 0.26 & 0.99 & $<0.0001$ \\
\hline $\mathrm{Al}[\mathrm{r}]-\mathrm{Al}[\mathrm{l}]$ & 35.05 & 3.81 & 35.20 & 3.87 & -0.15 & 0.89 & 0.44 & 0.98 & $<0.0001$ \\
\hline $\mathrm{Cph}[\mathrm{r}]-\mathrm{Cph}[\mathrm{l}]$ & 12.56 & 2.13 & 12.45 & 2.09 & 0.11 & 0.58 & 0.26 & 0.96 & $<0.0001$ \\
\hline Sn-Ls & 16.32 & 1.99 & 16.09 & 1.96 & 0.23 & 0.52 & 0.37 & 0.95 & $<0.0001$ \\
\hline Ls-Sto & 7.82 & 1.59 & 8.31 & 1.76 & -0.49 & 0.30 & 0.62 & 0.91 & $<0.0001$ \\
\hline Sn-Sto & 22.90 & 2.13 & 23.15 & 2.09 & -0.25 & 0.67 & 0.50 & 0.94 & $<0.0001$ \\
\hline $\mathrm{Li}-\mathrm{Sl}$ & 10.17 & 2.25 & 10.06 & 2.30 & 0.11 & 0.91 & 0.31 & 0.97 & $<0.0001$ \\
\hline Sto-Li & 10.12 & 2.00 & 9.85 & 2.01 & 0.27 & 0.53 & 0.50 & 0.94 & $<0.0001$ \\
\hline $\operatorname{Ex}[\mathrm{r}]-\operatorname{Ex}[1]$ & 87.93 & 4.81 & 89.58 & 4.74 & -1.65 & 0.18 & 1.70 & 0.91 & $<0.0001$ \\
\hline $\operatorname{En}[\mathrm{r}]-\mathrm{En}[\mathrm{l}]$ & 33.05 & 3.46 & 32.96 & 3.36 & 0.09 & 0.88 & 0.29 & 0.98 & $<0.0001$ \\
\hline En-Ex & 28.23 & 1.57 & 29.41 & 1.58 & -1.18 & 0.01 & 1.18 & 0.68 & $<0.0001$ \\
\hline N-Prn & 44.62 & 4.99 & 44.52 & 4.98 & 0.10 & 0.89 & 0.17 & 0.99 & $<0.0001$ \\
\hline Prn-Sn & 17.55 & 1.55 & 17.47 & 1.56 & 0.08 & 0.93 & 0.13 & 0.98 & $<0.0001$ \\
\hline Sl-Gn & 24.36 & 3.16 & 24.22 & 3.12 & 0.14 & 0.74 & 0.34 & 0.98 & $<0.0001$ \\
\hline $\operatorname{Tr}-\mathrm{Gn}$ & 182.98 & 11.59 & 182.55 & 11.83 & 0.43 & 0.87 & 0.62 & 0.99 & $<0.0001$ \\
\hline Sto-Gn & 42.62 & 3.94 & 42.06 & 3.70 & 0.56 & 0.57 & 0.64 & 0.97 & $<0.0001$ \\
\hline Chk[r]-Chk[l] & 83.07 & 5.55 & 82.79 & 5.46 & 0.28 & 0.78 & 0.58 & 0.98 & $<0.0001$ \\
\hline
\end{tabular}


Table 2. Differences between operators in the Vectra $\mathrm{H} 1$ portable system

\begin{tabular}{|c|c|c|c|c|c|c|c|c|}
\hline \multirow{2}{*}{ Distances } & \multicolumn{2}{|c|}{$1^{\text {st }}$ Operator, $\mathbf{H 1}$} & \multicolumn{2}{|c|}{$2^{\text {nd }}$ Operator, H1 } & \multirow{2}{*}{ MD } & \multirow{2}{*}{$p$} & \multirow{2}{*}{ MAD } & \multirow{2}{*}{ TEM } \\
\hline & Average & SD & Average & SD & & & & \\
\hline $\mathrm{T}[\mathrm{r}]-\mathrm{T}[\mathrm{l}]$ & 141.68 & 8.43 & 141.66 & 8.44 & 0.02 & 0.98 & 0.02 & 0.00 \\
\hline $\mathrm{Zy}[\mathrm{r}]-\mathrm{Zy}[\mathrm{l}]$ & 139.23 & 8.32 & 139.20 & 8.31 & 0.03 & 0.99 & 0.05 & 0.13 \\
\hline $\mathrm{Go}[\mathrm{r}]-\mathrm{Go}[\mathrm{l}]$ & 118.32 & 9.71 & 118.36 & 9.72 & -0.04 & 0.99 & 0.05 & 0.02 \\
\hline $\mathrm{Ch}[\mathrm{r}]-\mathrm{Ch}[\mathrm{l}]$ & 50.55 & 3.80 & 50.15 & 4.16 & 0.40 & 0.70 & 0.74 & 3.05 \\
\hline Tr-N & 70.57 & 9.02 & 70.53 & 8.96 & 0.04 & 0.99 & 0.09 & 0.06 \\
\hline $\mathrm{N}-\mathrm{Sn}$ & 50.46 & 4.40 & 50.48 & 4.39 & -0.02 & 0.93 & 0.11 & 0.09 \\
\hline Sn-Gn & 64.90 & 5.11 & 64.95 & 5.12 & -0.05 & 0.94 & 0.14 & 0.20 \\
\hline $\mathrm{T}[\mathrm{r}]-\mathrm{Go}[\mathrm{r}]$ & 59.61 & 6.07 & 59.57 & 6.09 & 0.04 & 1.00 & 0.10 & 0.10 \\
\hline $\mathrm{T}[\mathrm{l}]-\mathrm{Go}[\mathrm{l}]$ & 60.60 & 6.80 & 60.60 & 6.76 & 0.00 & 0.97 & 0.09 & 0.05 \\
\hline $\mathrm{N}-\mathrm{T}[\mathrm{r}]$ & 117.22 & 6.22 & 117.18 & 6.19 & 0.04 & 0.98 & 0.06 & 0.03 \\
\hline $\mathrm{N}-\mathrm{T}[\mathrm{l}]$ & 116.59 & 6.72 & 116.58 & 6.77 & 0.01 & 1.00 & 0.07 & 0.03 \\
\hline $\mathrm{Sn}-\mathrm{T}[\mathrm{r}]$ & 121.71 & 6.60 & 121.71 & 6.58 & 0.00 & 0.98 & 0.08 & 0.06 \\
\hline Sn-T[1] & 122.18 & 7.01 & 122.16 & 7.04 & 0.02 & 0.97 & 0.07 & 0.03 \\
\hline $\mathrm{Pg}-\mathrm{T}[\mathrm{r}]$ & 137.23 & 8.26 & 137.25 & 8.27 & -0.01 & 0.98 & 0.07 & 0.05 \\
\hline Pg-T[1] & 137.71 & 8.38 & 137.70 & 8.39 & 0.01 & 1.00 & 0.07 & 0.03 \\
\hline Pg-Go[r] & 94.67 & 7.20 & 94.70 & 7.17 & -0.03 & 1.00 & 0.06 & 0.03 \\
\hline Pg-Go[l] & 95.49 & 6.09 & 95.45 & 6.06 & 0.03 & 1.00 & 0.08 & 0.06 \\
\hline $\mathrm{Ft}[\mathrm{r}]-\mathrm{Ft}[\mathrm{l}]$ & 110.50 & 5.53 & 110.48 & 5.56 & 0.02 & 0.98 & 0.08 & 0.04 \\
\hline $\mathrm{Al}[\mathrm{r}]-\mathrm{Al}[\mathrm{l}]$ & 35.18 & 3.87 & 35.20 & 3.87 & -0.02 & 1.00 & 0.02 & 0.01 \\
\hline $\mathrm{Cph}[\mathrm{r}]-\mathrm{Cph}[\mathrm{l}]$ & 12.46 & 2.05 & 12.45 & 2.09 & 0.01 & 0.90 & 0.10 & 0.09 \\
\hline Sn-Ls & 16.02 & 1.92 & 16.09 & 1.96 & -0.07 & 0.95 & 0.13 & 0.16 \\
\hline Ls-Sto & 8.27 & 1.72 & 8.31 & 1.76 & -0.04 & 0.94 & 0.15 & 0.17 \\
\hline Sn-Sto & 23.09 & 2.07 & 23.15 & 2.09 & -0.06 & 0.85 & 0.13 & 0.14 \\
\hline $\mathrm{Li}-\mathrm{Sl}$ & 10.03 & 2.20 & 10.06 & 2.30 & -0.03 & 0.86 & 0.17 & 0.33 \\
\hline Sto-Li & 9.91 & 1.84 & 9.85 & 2.01 & 0.07 & 0.80 & 0.23 & 0.55 \\
\hline $\operatorname{Ex}[\mathrm{r}]-\operatorname{Ex}[1]$ & 89.93 & 4.75 & 89.54 & 4.76 & 0.38 & 0.87 & 0.44 & 1.23 \\
\hline $\operatorname{En}[\mathrm{r}]-\mathrm{En}[\mathrm{l}]$ & 32.56 & 3.30 & 32.97 & 3.36 & -0.41 & 0.59 & 0.45 & 1.38 \\
\hline En-Ex & 29.81 & 1.53 & 29.37 & 1.56 & 0.44 & 0.43 & 0.46 & 1.33 \\
\hline N-Prn & 44.52 & 4.99 & 44.52 & 4.98 & 0.00 & 0.98 & 0.04 & 0.02 \\
\hline Prn-Sn & 17.48 & 1.56 & 17.47 & 1.56 & 0.01 & 0.94 & 0.10 & 0.06 \\
\hline Sl-Gn & 24.16 & 3.21 & 24.22 & 3.12 & -0.06 & 0.87 & 0.15 & 0.28 \\
\hline $\operatorname{Tr}-\mathrm{Gn}$ & 182.54 & 11.88 & 182.55 & 11.83 & -0.01 & 0.99 & 0.15 & 0.21 \\
\hline Sto-Gn & 42.06 & 3.70 & 42.06 & 3.70 & 0.00 & 0.97 & 0.16 & 0.21 \\
\hline $\operatorname{Chk}[\mathrm{r}]-\mathrm{Chk}[\mathrm{l}]$ & 82.84 & 5.48 & 82.79 & 5.46 & 0.05 & 0.96 & 0.08 & 0.12 \\
\hline
\end{tabular}

Figure 3 shows 2 charts; Chart 1 is a Bland-Altman's agreement analysis referring to the distance $\mathrm{T}[\mathrm{r}]-\mathrm{T}[\mathrm{l}]$ obtained by the portable Vectra $\mathrm{H} 1$ system for all 30 participants. Chart 2, also a Bland-Altman's agreement analysis, refers to the distance $4-6$ obtained by the Vectra H1 portable system for the cube. 
Chart 1 - Bland-Altman's method for agreement analysis of the linear distance values between the reference points $\mathrm{T}[\mathrm{r}]$ and $\mathrm{T}[\mathrm{l}]$ in participants presented by Vectra $\mathrm{H} 1$ portable system

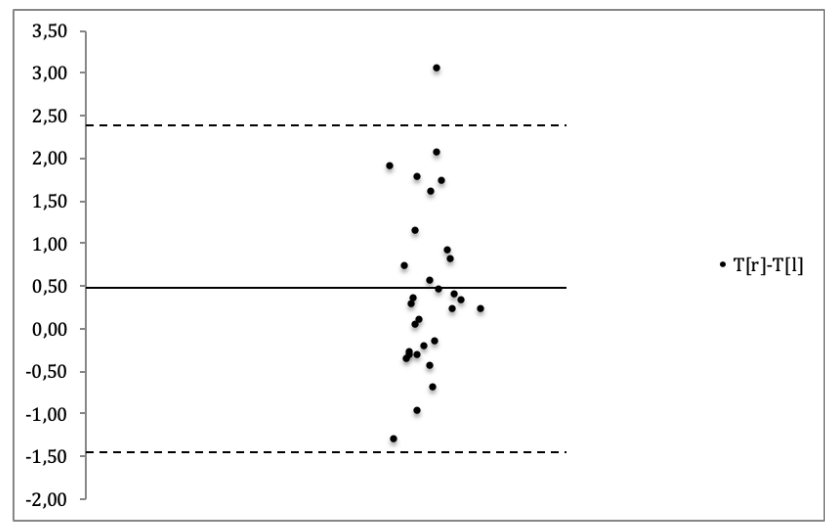

Chart 2 - Bland-Altman's method for distances between points 4 and 6 for images captured by the Vectra $\mathrm{H} 1$ portable system

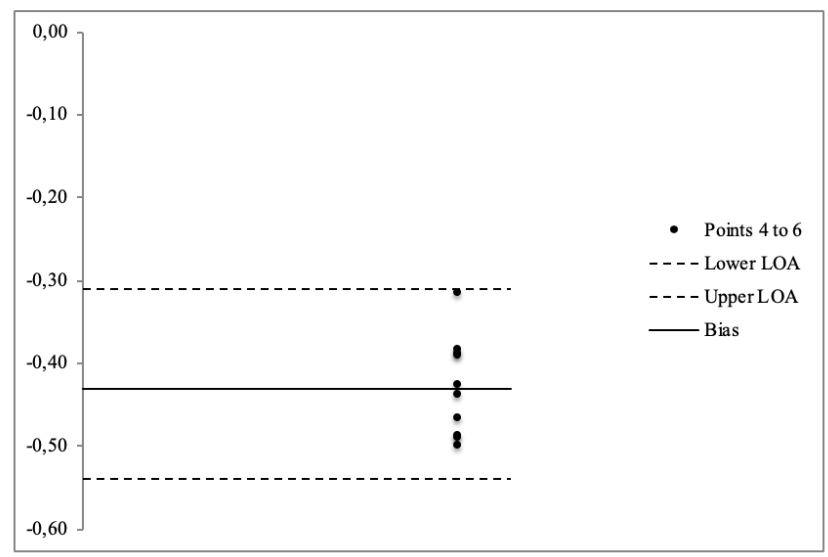

Figure 3. Chart 1 is of Bland-Altman's agreement analysis, referring to the distance $T[r]-T[l]$ obtained by the portable Vectra $\mathrm{H} 1$ system for all 30 participants. Chart 2, also of Bland-Altman's agreement analysis, refers to the distance 4-6 obtained by the Vectra $\mathrm{H} 1$ portable system for the cube.

The errors obtained for $90^{\circ}$ angles on areas away from the edges in 2 images, both captured by Vectra H1 with same operator were REM 0.39 for the first and second captures, DM -0.1, MAD 0.35 and TEM 0.5. Table 3 shows the values obtained for linear distances on areas out of edge in 10 images, comparing both stereophotogrammetry systems. Table 4 presents the TEM of linear distances for captures of the cube by the Vectra H1 and M3 systems (repeatability test).

Table 3. Linear distances on areas away from the edges in 10 images, in both systems

\begin{tabular}{|c|c|c|c|c|c|c|c|}
\hline \multirow{2}{*}{ Distances } & \multicolumn{2}{|c|}{ H1 } & \multicolumn{2}{|c|}{ M3 } & \multirow{2}{*}{ MD } & \multirow{2}{*}{ MAD } & \multirow{2}{*}{ REM \% } \\
\hline & Average & SD & Average & SD & & & \\
\hline 1 to 3 & 69.72 & 0.04 & 70.15 & 0.08 & -0.43 & 0.43 & 0.61 \\
\hline 4 to 6 & 69.73 & 0.05 & 70.16 & 0.04 & -0.43 & 0.43 & 0.61 \\
\hline 7 to 9 & 69.72 & 0.05 & 70.16 & 0.06 & -0.44 & 0.44 & 0.63 \\
\hline 10 to 12 & 70.06 & 0.14 & 70.52 & 0.06 & -0.46 & 0.45 & 0.65 \\
\hline 13 to 15 & 70.08 & 0.10 & 70.38 & 0.08 & -0.30 & 0.30 & 0.43 \\
\hline 16 to 18 & 70.06 & 0.05 & 70.17 & 0.09 & -0.11 & 0.13 & 0.18 \\
\hline 19 to 21 & 69.76 & 0.06 & 70.14 & 0.07 & -0.38 & 0.38 & 0.55 \\
\hline 22 to 24 & 69.76 & 0.07 & 70.14 & 0.04 & -0.38 & 0.37 & 0.53 \\
\hline 25 to 27 & 69.80 & 0.08 & 70.16 & 0.05 & -0.36 & 0.36 & 0.52 \\
\hline
\end{tabular}


Table 4. Linear distances in different captures of Vectra $\mathrm{H} 1$ and $\mathrm{M} 3$ portable system, showing TEM to test the system's repeatability

\begin{tabular}{|c|c|c|c|c|}
\hline \multirow{2}{*}{ Distances } & \multicolumn{2}{|c|}{ H1 } & \multicolumn{2}{|c|}{ M3 } \\
\hline & $1^{\text {st }}$ capture & $2^{\text {nd }}$ capture & $1^{\text {st }}$ capture & $2^{\text {nd }}$ capture \\
\hline 1 to 3 & 69.74 & 69.75 & 70,17 & 70,18 \\
\hline 4 to 6 & 69.73 & 69.77 & 70,17 & 70,15 \\
\hline 7 to 9 & 69.76 & 69.77 & 70,16 & 70,13 \\
\hline 10 to 12 & 70.17 & 70.20 & 70,54 & 70,49 \\
\hline 13 to 15 & 70.12 & 70.08 & 70,38 & 70,30 \\
\hline 16 to 18 & 70.00 & 70.09 & 70,19 & 70,13 \\
\hline 19 to 21 & 69.79 & 69.80 & 70,12 & 70,17 \\
\hline 22 to 24 & 69.83 & 69.82 & 70,12 & 70,13 \\
\hline 25 to 27 & 69.84 & 69.87 & 70,15 & 70,20 \\
\hline Average & 69.89 & 69.91 & 70,22 & 70,21 \\
\hline SD & 0.17 & 0.17 & 0,14 & 0,12 \\
\hline Minimum & 69.73 & 69.75 & 70,12 & 70,13 \\
\hline Maximum & 70.17 & 70.20 & 70,54 & 70,49 \\
\hline REM & 0.04 & 0.04 & 0,06 & 0,06 \\
\hline MD & \multicolumn{2}{|c|}{-0.02} & \multicolumn{2}{|c|}{0.01} \\
\hline MAD & \multicolumn{2}{|c|}{0.03} & \multicolumn{2}{|c|}{0.04} \\
\hline TEM & \multicolumn{2}{|c|}{0.00} & \multicolumn{2}{|c|}{0.00} \\
\hline
\end{tabular}

\section{DISCUSSION}

While direct anthropometry has always been accepted as the gold standard in facial analysis because of its simplicity and low cost, the need for long clinical sessions and well-trained examiners has been a hindrance ${ }^{30-32}$. Stereophotogrammetry presents a safe, non-invasive technique free of ionizing radiation in longitudinal studies ${ }^{33}$. Several papers present promising results for the use of this technique, but inconsistent terminologies and statistical tests for error analysis are a challenge. Comparing any type of systems becomes more difficult without standardization in experiment designs. The literature presents studies that base analyses on the distance between landmarks ${ }^{14,34,35}$ and on angular measurements ${ }^{34,36,37}$, linear distances $2,12,38,39$ and maps that highlight morphological differences between surfaces by means of colors ${ }^{40-42}$.

Inanimate objects have been used in previous studies, which has the advantage of not skewing results with involuntary movements $11,38,40,43,44$. This is why we also adopted an inanimate model as part of this work: changes in soft tissue from involuntary movements could alter the results in such a manner that these differences could be improperly interpreted as inaccuracies of stereophotogrammetry systems. Thus, it is understandable that more accurate results are obtained when distances are analyzed on inanimate objects than on humans. It is important to have full knowledge of the peculiarities of each piece of equipment used and to have control of the participant during image capture 28,36 to minimize possible errors from participants' inadvertent movements.

Errors in the identification of landmarks and during the capture of images are the main sources of error in the stereophotogrammetry technique ${ }^{45}$. As the present study focused on evaluating the accuracy of the Vectra $\mathrm{H} 1$ portable system and not the operators' marking accuracy, the images captured by this system and the Vectra M3 fixed system used the same landmarks for the participants and the cube, allowing any discrepancies in the obtained distances to be attributed to inaccuracies in image capturing or the software's analysis procedure. In other words, benchmarking at separate moments would add differences between measurements not related to the accuracy of each stereophotogrammetry system itself but 
rather to the operator. Thus, it would be necessary to separate operator errors from system inaccuracies. Another reason to capture participants' images at the same time for both systems was to avoid effects of age, weight and posture changes that could generate discrepancies in the measurements $27,35,46$.

Various error limits for precision are used in the literature. Metzger et al. ${ }^{47}$ considered $3 \mathrm{~mm}$ as the acceptable limit for errors, whereas Weinberg et al. ${ }^{10}$ and Moshkelgosha, Shamsa ${ }^{48}$ used as reference errors of up to $2 \mathrm{~mm}$ or 2 units of the measure used. Aldridge et al. ${ }^{14}$, de Menezes et al. ${ }^{2}$ and Dindaroğlu et al. ${ }^{37}$ defined the accuracy error limit as only $1 \mathrm{~mm}$. Lübbers et al. ${ }^{35}$ pointed out that even experienced observers aren't able to identify differences smaller than $1.5 \mathrm{~mm}$ in most facial structures without the use of equipment. The measurement that presented the greatest mean difference between both systems was the distance Ex[r]-Ex[l] of $1.65 \mathrm{~mm}$. The reasons for this finding are the difficulty of image capture in this area due to the presence of cilia and changes in the image's texture (skin and eyes). As the setting of these landmarks is done directly on the computer, the lack of previous marking with eyeliner increases the chances of error ${ }^{2}$. The measurement with previous markings that presented the greatest mean difference was Go[r]-Go[l] with a difference of $1.31 \mathrm{~mm}$. The distance that presented the smallest mean difference was Sn-T[l] with a difference of only $0.04 \mathrm{~mm}$. The mean difference of the measurements between the two stereophotogrammetry systems was $0.36 \mathrm{~mm}$ for the linear distances obtained from the participants.

When the cube's linear distances were compared between the two systems, the lowest average difference was $0.11 \mathrm{~mm}$, and the highest was $0.46 \mathrm{~mm}$. The average difference of measurements of each system was $0.27 \mathrm{~mm}$, far below all limits proposed by any authors previously mentioned. When comparing the average of linear distances between the two stereophotogrammetry systems, no results showed statistically significant differences $(p>.05)$. ICC remained high at all distances, thus presenting extremely low $p$ of ICC values $(<0.0001)$. This shows a high correlation between the averages of measurements between both systems.

The MAD is commonly used as an estimate of accuracy ${ }^{10,13}$. Again, Ex[r]-Ex[l] was the distance that presented the highest value of 1.70 . Go[r]-Go[l] was, again, the linear distance previously defined by landmarks that presented the highest MAD value of 1.38. The MAD values described above were found by comparing the two stereophotogrammetry systems. When we observe the MAD values for the Vectra H1 portable system (comparing the results obtained by different operators), we find the distances $\mathrm{T}[\mathrm{r}]-\mathrm{T}[\mathrm{l}]$ and $\mathrm{Al}[\mathrm{r}]-\mathrm{Al}[\mathrm{l}]$ to have the lowest values of 0.02 . The distance with the highest MAD value was $\mathrm{Ch}[\mathrm{r}]-\mathrm{Ch}[1]$ (mouth width) at 0.74 ; this result for mouth width matches that obtained by de Menezes et al.2. who also found the highest MAD value at this distance. However, the value obtained by this author was slightly higher $(0.90)$ using the Vectra M3 fixed system.

The TEM was obtained only in comparisons between measurements of the same apparatus. Some studies have used this statistical test to compare measurements of different devices, but this practice is not unanimous - the studies that have used TEM did so for the same measurements with the same evaluated device $2,36,44$. According to Perini et al. ${ }^{49}$, the TEM test would only apply to the measurements performed and the equipment used. That is, TEM values should be related only to measurements from the same apparatus, not to measurements from two devices. For this reason, the TEM test was used in this work only when comparing the same measurements from the same apparatus in different captures. The highest TEM values were found for linear distances that were obtained by means of landmarks marked directly on the computer, namely $\mathrm{Ch}[\mathrm{r}]-\mathrm{Ch}[\mathrm{l}](\mathrm{TEM}=3.05), \mathrm{Ex}[\mathrm{r}]-\mathrm{Ex}[\mathrm{l}](\mathrm{TEM}=1.23)$ and En-Ex $(\mathrm{TEM}=1.33)$. The highest TEM value for a distance defined by landmarks marked directly on a participant's face was Li-Sl at only 0.33 . The lowest TEM value found was for T[r] -T[l] at 0.00. de Menezes et al. ${ }^{2}$ conducted this same statistical test between operators but with the Vectra M3 fixed system. The authors found the highest TEM value for $\mathrm{Ch}[\mathrm{r}]-\mathrm{Ch}[\mathrm{l}]$ at 0.81 and the lowest 
TEM value for $\mathrm{Zy}[\mathrm{r}]-\mathrm{Zy}[\mathrm{l}]$ at 0.05 . It is important to emphasize that de Menezes et al. ${ }^{2}$ evaluated only 16 distances in their work, which limits comparisons with this study.

At the end of 2017, Camison et al. ${ }^{26}$ carried out a study with the same purpose as the present study. The authors compared the Vectra $\mathrm{H} 1$ portable system with a fixed one already established in the literature. They began their work with 26 participants but were able to analyze only 23 of them due to failures to capture landmarks near the ears. Although they do not cite which landmarks these were, we believe they must have been T[r] and T[l], since we also noted the need for special care with the capture of these areas, very close to the capture limit of the systems. In our study, after capturing each image, we took time to verify that all of the landmarks had been correctly captured by each system before dismissing the participant. This way, we avoided the misfortune of a diminished sample and were able to perform new captures as necessary. One of the statistical tests used by Camison et al.26, TEM, was also performed in our study. However, Camison et al. ${ }^{26}$ used that test to compare measurements between two stereophotogrammetry systems. As explained previously, the TEM test was performed in our work only to compare the same measurements from the same system.

A very interesting statistical test that does not appear in Camison et al.26 is the Bland-Altman test. According to Hirakata et al. ${ }^{50}$, agreement between methods is not properly evaluated when using the correlation coefficient, as it does not evaluate agreement, only association. The authors suggest the Bland-Altman test to analyze agreement between two methods. Codari et al. ${ }^{51}$ used the Bland-Altman scatter plot in his study, in which he assessed the symmetry of facial thirds in patients with facial paralysis using the Vectra M3 fixed system. The author and his colleagues used Bland-Altman to analyze the repeatability of measurements of lower, middle and upper thirds and left and right sides of the face as well as the entire face surface (total of 7 charts). In all thirds, the line showing the mean of the measurements remained close to 0 , indicating an absence of systematic errors. All Bland-Altman scatter charts for the performed measurements showed precise dispersions in the present work. However, as stated previously, due to the large number of Bland-Altman charts, they could not all be included in this paper.

As for the results obtained by analysis of the cube, the angular measures presented extremely accurate results for both systems with averages of $90^{\circ}$. The analysis of the linear distances of the cube shows that for all measurements, the values obtained by the Vectra H1 were lower than those presented by the Vectra M3 fixed system. For the three distances obtained on the right side of the cube, the mean values presented by Vectra M3 were higher than the actual value of $70 \mathrm{~mm}$, and the average values of $\mathrm{H} 1$ were lower than $70 \mathrm{~mm}$. The three averages presented by the Vectra M3 were closer to the real value of $70 \mathrm{~mm}$. For the three distances of the upper face of the cube, the average of Vectra M3's values remained higher than that of H1. However, these three mean distances were closer to the actual values from the Vectra $\mathrm{H} 1$ portable system. Finally, the left side of the cube presented average distances in a similar way to the right side: the three averages of distances obtained by the Vectra M3 were larger than those presented by the Vectra H1, being also closer to the real value of $70 \mathrm{~mm}$.

Briefly, it was observed that the Vectra M3 fixed system was more accurate for linear distances on the sides of the cube, while the Vectra $\mathrm{H} 1$ portable system obtained averages closer to the real distances on the upper face of the cube. It is interesting to point out that in all 9 analyzed distances, the Vectra M3 fixed system presented higher average values than the Vectra H1, with the distance 16-18 (upper face, closest to the center of the image) being the region where the two systems obtained the closest results.

Such systematic occurrences of higher values for M3 in relation to $\mathrm{H} 1$ are only observed in analysis of the cube, not being present in participants' images. This was probably due to small changes in soft tissue position between captures. As conscious as the participants were of the need for immobility during the imaging capture, minimal head position changes and slight 
contractions of facial expression muscles and mandibular position may have introduced small errors during image capture. Both stereophotogrammetry systems, therefore, showed excellent repeatability.

In observing the overlapping of two distinct images of the cube captured by the Vectra H1, it is clear that the distance between the points was very close. The points with the smallest distance between the image surfaces were points $7 \mathrm{a}-7 \mathrm{~b}$ and $20 \mathrm{a}-20 \mathrm{~b}$ at $0.01 \mathrm{~mm}$. The points that presented the greatest distance were $12 \mathrm{a}-12 \mathrm{~b}$ at $0.18 \mathrm{~mm}$. Although all distances were extremely small (average of only $0.07 \mathrm{~mm}$ ), we noticed that the points marked on the upper face of the cube tended to be more distant from each other in the overlapping images, especially as they moved away from the anterior region of the cube. The landmarks on the lateral faces also tended to show slightly higher distance values as they moved away from the anterior region of the cube.

\section{CONCLUSION}

The results obtained by the established methodology and correlation with previous findings in the literature allowed for the conclusion that the Vectra H1 portable system presented accuracy and repeatability comparable to the fixed Vectra M3 system, showing an ability to capture three-dimensional images effectively; this makes it adequate for use in most diverse clinical applications. Its portable nature will surely find great utility in obtaining accurate and replicable three-dimensional images in situations in which the analyzed subject cannot travel or be moved to a fixed stereophotogrammetry system for systemic or logistic reasons.

\section{REFERENCES}

1. Farkas L. Anthropometry of the head and face. 2nd ed. New York: Raven Press; 1994. p.3-56.

2. de Menezes M, Rosati R, Ferrario VF, Sforza C. Accuracy and reproducibility of a 3-dimensional stereophotogrammetric imaging system. J Oral Maxillofac Surg. 2010 Sep;68(9):2129-35. http://dx.doi.org/10.1016/j.joms.2009.09.036. PMid:20646812.

3. Hennessy RJ, McLearie S, Kinsella A, Waddington JL. Facial surface analysis by 3D laser scanning and geometric morphometrics in relation to sexual dimorphism in cerebral-craniofacial morphogenesis and cognitive function. J Anat. 2005 Sep;207(3):283-95. http://dx.doi.org/10.1111/j.1469-7580.2005.00444.x. PMid:16185253.

4. Tollefson TT, Sykes JM. Computer imaging software for profile photograph analysis. Arch Facial Plast Surg. 2007 Mar-Apr;9(2):113-9. http://dx.doi.org/10.1055/s-2007-979280. PMid:17372065.

5. Kochel J, Meyer-Marcotty P, Strnad F, Kochel M, Stellzig-Eisenhauer A. 3D soft tissue analysis--part 1: sagittal parameters. J Orofac Orthop. 2010 Jan;71(1):40-52. http://dx.doi.org/10.1007/s00056-010-9926-x. PMid:20135249.

6. Sforza C, Ferrario VF. Three-dimensional analysis of facial morphology: growth, development and aging of the orolabial region. Ital J Anat Embryol. 2010;115(1-2):141-5. PMid:21073004.

7. Mutsvangwa TE, Veeraragoo M, Douglas TS. Precision assessment of stereo-photogrammetrically derived facial landmarks in infants. Ann Anat. 2011 Mar;193(2):100-5. http://dx.doi.org/10.1016/j.aanat.2010.10.008. PMid:21167694.

8. Ritz-Timme S, Gabriel P, Tutkuviene J, Poppa P, Obertová Z, Gibelli D, et al. Metric and morphological assessment of facial features: a study on three European populations. Forensic Sci Int. 2011 Apr;207(13):239.e1-8. http://dx.doi.org/10.1016/j.forsciint.2011.01.035. PMid:21388762.

9. Verzé L, Nasi A, Quaranta F, Vasino V, Prini V, Ramieri G. Quantification of facial movements by surface laser scanning. J Craniofac Surg. 2011 Jan;22(1):60-5. http://dx.doi.org/10.1097/SCS.0b013e3181f6c46d. PMid:21187777. 
10. Weinberg SM, Scott NM, Neiswanger K, Brandon CA, Marazita ML. Digital three-dimensional photogrammetry: evaluation of anthropometric precision and accuracy using a Genex 3D camera system. Cleft Palate Craniofac J. 2004 Sep;41(5):507-18. http://dx.doi.org/10.1597/03-066.1. PMid:15352857.

11. Weinberg SM, Naidoo S, Govier DP, Martin RA, Kane AA, Marazita ML. Anthropometric precision and accuracy of digital three-dimensional photogrammetry: comparing the Genex and 3dMD imaging systems with one another and with direct anthropometry. J Craniofac Surg. 2006 May;17(3):477-83. http://dx.doi.org/10.1097/00001665-200605000-00015. PMid:16770184.

12. Ghoddousi H, Edler R, Haers P, Wertheim D, Greenhill D. Comparison of three methods of facial measurement. Int J Oral Maxillofac Surg. 2007 Mar;36(3):250-8. http://dx.doi.org/10.1016/j.ijom.2006.10.001. PMid:17113754.

13. Wong JY, Oh AK, Ohta E, Hunt AT, Rogers GF, Mulliken JB, et al. Validity and reliability of craniofacial anthropometric measurement of 3D digital photogrammetric images. Cleft Palate Craniofac J. 2008 May;45(3):232-9. http://dx.doi.org/10.1597/06-175. PMid:18452351.

14. Aldridge K, Boyadjiev SA, Capone GT, DeLeon VB, Richtsmeier JT. Precision and error of three-dimensional phenotypic measures acquired from 3dMD photogrammetric images. Am J Med Genet A. 2005 Oct;138A(3):247-53. http://dx.doi.org/10.1002/ajmg.a.30959. PMid:16158436.

15. Deli R, Di Gioia E, Galantucci LM, Percoco G. Automated landmark extraction for orthodontic measurement of faces using the 3-camera photogrammetry methodology. J Craniofac Surg. 2010 Jan;21(1):87-93. http://dx.doi.org/10.1097/SCS.0b013e3181c3ba74. PMid:20072024.

16. Nute SJ, Moss JP. Three-dimensional facial growth studied by optical surface scanning. J Orthod. 2000 Mar;27(1):31-8. http://dx.doi.org/10.1093/ortho/27.1.31. PMid:10790442.

17. Talbert L, Kau CH, Christou T, Vlachos C, Souccar N. A 3D analysis of Caucasian and African American facial morphologies in a US population. J Orthod. 2014 Mar;41(1):19-29. http://dx.doi.org/10.1179/1465313313Y.0000000077. PMid:24671286.

18. Weinberg SM, Raffensperger ZD, Kesterke MJ, Heike CL, Cunningham ML, Hecht JT, et al. The 3D facial norms database: part 1. A web-based craniofacial anthropometric and image repository for the clinical and research community. Cleft Palate Craniofac J. 2016 Nov;53(6):e185-97. http://dx.doi.org/10.1597/15-199. PMid:26492185.

19. Farkas LG. Accuracy of anthropometric measurements: past, present, and future. Cleft Palate Craniofac J. 1996 Jan;33(1):10-8. http://dx.doi.org/10.1597/1545-1569_1996_033_0010_aoampp_2.3.co_2. PMid:8849854.

20. Farkas LG, Katic MJ, Forrest CR, Alt KW, Bagic I, Baltadjiev G, et al. International anthropometric study of facial morphology in various ethnic groups/races. J Craniofac Surg. 2005 Jul;16(4):615-46. http://dx.doi.org/10.1097/01.scs.0000171847.58031.9e. PMid:16077306.

21. Gwilliam JR, Cunningham SJ, Hutton T. Reproducibility of soft tissue landmarks on three-dimensional facial scans. Eur J Orthod. 2006 Oct;28(5):408-15. http://dx.doi.org/10.1093/ejo/cj1024. PMid:16901962.

22. Schimmel M, Christou P, Houstis O, Herrmann FR, Kiliaridis S, Müller F. Distances between facial landmarks can be measured accurately with a new digital 3-dimensional video system. Am J Orthod Dentofacial Orthop. 2010 May;137(5):580.e1-10. http://dx.doi.org/10.1016/j.ajodo.2009.03.039. PMid:20451768.

23. Fourie Z, Damstra J, Gerrits PO, Ren Y. Evaluation of anthropometric accuracy and reliability using different three-dimensional scanning systems. Forensic Sci Int. 2011 Apr;207(1-3):127-34. http://dx.doi.org/10.1016/j.forsciint.2010.09.018. PMid:20951517.

24. Junqueira Júnior AA, Magri LV, Melchior MO, Rodrigues da Silva AMB, Rodrigues da Silva MAM. Facial anthropometric analysis of a healthy group of young Brazilian adults by means of stereophotogrammetry technique. Rev Odontol UNESP. 2016 Jun;45(3):139-45. http://dx.doi.org/10.1590/1807-2577.19615. 
25. Andrade LM, Rodrigues da Silva AMB, Magri LV, Rodrigues da Silva MAM. Repeatability study of angular and linear measurements on facial morphology analysis by means of stereophotogrammetry. J Craniofac Surg. 2017 Jun;28(4):1107-11. http://dx.doi.org/10.1097/SCS.0000000000003554. PMid:28212123.

26. Camison L, Bykowski M, Lee WW, Carlson JC, Roosenboom J, Goldstein JA, et al. Validation of the Vectra H1 portable three-dimensional photogrammetry system for facial imaging. Int J Oral Maxillofac Surg. 2018 Mar;47(3):403-10. http://dx.doi.org/10.1016/j.ijom.2017.08.008. PMid:28919165.

27. Aynechi N, Larson BE, Leon-Salazar V, Beiraghi S. Accuracy and precision of a 3D anthropometric facial analysis with and without landmark labeling before image acquisition. Angle Orthod. 2011 Mar;81(2):24552. http://dx.doi.org/10.2319/041810-210.1. PMid:21208076.

28. Metzler P, Bruegger LS, Kruse Gujer AL, Matthews F, Zemann W, Graetz KW, et al. Craniofacial landmarks in young children: how reliable are measurements based on 3-dimensional imaging? J Craniofac Surg. 2012 Nov;23(6):1790-5. http://dx.doi.org/10.1097/SCS.0b013e318270fa8f. PMid:23147340.

29. Ferrario VF, Sforza C, Poggio CE, Cova M, Tartaglia G. Preliminary evaluation of an electromagnetic threedimensional digitizer in facial anthropometry. Cleft Palate Craniofac J. 1998 Jan;35(1):9-15. http://dx.doi.org/10.1597/1545-1569_1998_035_0009_peoaet_2.3.co_2.PMid:9482218.

30. Staudt CB, Kiliaridis S. A nonradiographic approach to detect Class III skeletal discrepancies. Am J Orthod Dentofacial Orthop. 2009 Jul;136(1):52-8. http://dx.doi.org/10.1016/j.ajodo.2007.07.025. PMid:19577148.

31. Baik HS, Kim SY. Facial soft-tissue changes in skeletal Class III orthognathic surgery patients analyzed with 3-dimensional laser scanning. Am J Orthod Dentofacial Orthop. 2010 Aug;138(2):167-78. http://dx.doi.org/10.1016/j.ajodo.2010.02.022. PMid:20691358.

32. Kim HH, Lee JW, Cha KS, Chung DH, Lee SM. Three-dimensional assessment of upper lip positional changes according to simulated maxillary anterior tooth movements by white light scanning. Korean J Orthod. 2014 Nov;44(6):281-93. http://dx.doi.org/10.4041/kjod.2014.44.6.281. PMid:25473644.

33. Schaaf H, Malik CY, Howaldt HP, Streckbein P. Evolution of photography in maxillofacial surgery: from analog to 3D photography - an overview. Clin Cosmet Investig Dent. 2009 Sep;1:39-45. https://doi.org/10.2147/ccide.s6760.

34. Lübbers HT, Medinger L, Kruse A, Grätz KW, Matthews F. Precision and accuracy of the 3dMD photogrammetric system in craniomaxillofacial application. J Craniofac Surg. 2010 May;21(3):763-7. http://dx.doi.org/10.1097/SCS.0b013e3181d841f7. PMid:20485043.

35. Lübbers HT, Medinger L, Kruse AL, Grätz KW, Obwegeser JA, Matthews F. The influence of involuntary facial movements on craniofacial anthropometry: a survey using a three-dimensional photographic system. Br J Oral Maxillofac Surg. 2012 Mar;50(2):171-5. http://dx.doi.org/10.1016/j.bjoms.2010.12.002. PMid:21236527.

36. de Menezes M, Rosati R, Allievi C, Sforza C. A photographic system for the three-dimensional study of facial morphology. Angle Orthod. 2009 Nov;79(6):1070-7. http://dx.doi.org/10.2319/111008-570. PMid:19852596.

37. Dindaroğlu F, Kutlu P, Duran GS, Görgülü S, Aslan E. Accuracy and reliability of 3D stereophotogrammetry: A comparison to direct anthropometry and 2D photogrammetry. Angle Orthod. 2016 May;86(3):487-94. http://dx.doi.org/10.2319/041415-244.1. PMid:26267357.

38. Winder RJ, Darvann TA, McKnight W, Magee JD, Ramsay-Baggs P. Technical validation of the Di3D stereophotogrammetry surface imaging system. Br J Oral Maxillofac Surg. 2008 Jan;46(1):33-7. http://dx.doi.org/10.1016/j.bjoms.2007.09.005. PMid:17980940.

39. Heike CL, Cunningham ML, Hing AV, Stuhaug E, Starr JR. Picture perfect? Reliability of craniofacial anthropometry using three-dimensional digital stereophotogrammetry. Plast Reconstr Surg. 2009 Oct;124(4):1261-72. http://dx.doi.org/10.1097/PRS.0b013e3181b454bd. PMid:19935311.

40. Artopoulos A, Buytaert JA, Dirckx JJ, Coward TJ. Comparison of the accuracy of digital stereophotogrammetry and projection moiré profilometry for three-dimensional imaging of the face. Int J 
Oral Maxillofac Surg. 2014 May;43(5):654-62. http://dx.doi.org/10.1016/j.ijom.2013.10.005. PMid:24225265.

41. Liu Y, Kau CH, Talbert L, Pan F. Three-dimensional analysis of facial morphology. J Craniofac Surg. 2014 Sep;25(5):1890-4. http://dx.doi.org/10.1097/01.SCS.0000436677.51573.a6. PMid:25072972.

42. Kornreich D, Mitchell AA, Webb BD, Cristian I, Jabs EW. Quantitative assessment of facial asymmetry using three-dimensional surface imaging in adults: validating the precision and repeatability of a global approach. Cleft Palate Craniofac J. 2016 Jan;53(1):126-31. http://dx.doi.org/10.1597/13-353. PMid:25489769.

43. Galantucci LM, Percoco G, Lavecchia F, Di Gioia E. Noninvasive computerized scanning method for the correlation between the facial soft and hard tissues for an integrated three-dimensional anthropometry and cephalometry. J Craniofac Surg. 2013 May;24(3):797-804.

http://dx.doi.org/10.1097/SCS.0b013e31828dcc81. PMid:23714883.

44. De Menezes M, Cerón-Zapata AM, López-Palacio AM, Mapelli A, Pisoni L, Sforza C. Evaluation of a threedimensional stereophotogrammetric method to identify and measure the palatal surface area in children with unilateral cleft lip and palate. Cleft Palate Craniofac J. 2016 Jan;53(1):16-21. http://dx.doi.org/10.1597/14-076. PMid:25794014.

45. Ferrario VF, Sforza C, Schmitz JH, Santoro F. Three-dimensional facial morphometric assessment of soft tissue changes after orthognathic surgery. Oral Surg Oral Med Oral Pathol Oral Radiol Endod. 1999 Nov;88(5):549-56. http://dx.doi.org/10.1016/S1079-2104(99)70084-3. PMid:10556748.

46. Al Ali A, Richmond S, Popat H, Toma AM, Playle R, Zhurov AI, et al. The influence of asthma on face shape: a three-dimensional study. Eur J Orthod. 2014 Aug;36(4):373-80. http://dx.doi.org/10.1093/ejo/cjs067. PMid:25074563.

47. Metzger TE, Kula KS, Eckert GJ, Ghoneima AA. Orthodontic soft-tissue parameters: a comparison of conebeam computed tomography and the 3dMD imaging system. Am J Orthod Dentofacial Orthop. 2013 Nov;144(5):672-81. http://dx.doi.org/10.1016/j.ajodo.2013.07.007. PMid:24182583.

48. Moshkelgosha V, Shamsa M. Introduction of aesthetic analyser software: computer-aided linear and angular analysis of facial profiles photographs. J Dent Shiraz Univ Med Scien. 2012 Jun;13(2):64-7.

49. Perini TA, Oliveira GL, Ornellas JS, Oliveira FP. Technical error of measurement in anthropometry. Rev Bras Med Esporte. 2005 Fev;11(1):81-5. http://dx.doi.org/10.1590/S1517-86922005000100009.

50. Hirakata VN, Camey SA. Análise de concordância entre métodos de Bland-Altman. Rev HCPA. 2009;29(3):261-8.

51. Codari M, Pucciarelli V, Stangoni F, Zago M, Tarabbia F, Biglioli F, et al. Facial thirds-based evaluation of facial asymmetry using stereophotogrammetric devices: application to facial palsy subjects. J Craniomaxillofac Surg. 2017 Jan;45(1):76-81. http://dx.doi.org/10.1016/j.jcms.2016.11.003. PMid:27939040.

\section{CONFLICTS OF INTERESTS}

The authors declare no conflicts of interest.

\section{*CORRESPONDING AUTHOR}

Alvaro Augusto Junqueira-Júnior, USP - Universidade de São Paulo, Faculdade de Odontologia de Ribeirão Preto, Departamento de Odontologia Restauradora, Ribeirão Preto SP, Brasil, e-mail: aaajunqueira@gmail.com

Received: September 23, 2019

Accepted: November 11, 2019 